\title{
ANALISIS STANDAR BELANJA UNTUK PENYUSUNAN RKA-APBD KEGIATAN PENYEDIAAN BAHAN BACAAN (Studi pada SKPD di Pemerintah Kabupaten Lumajang Tahun 2015)
}

\author{
Meilinda Trisilia,S.Si.,M.Si. \\ Universitas Ma Chung \\ meilinda.trisilia@machung.ac.id
}

\begin{abstract}
Abstrak
Tuntutan transparansi dan akuntabilitas atas pengelolaan keuangan daerah semakin meningkat, karenanya untuk memenuhi tuntutan tersebut diperlukan pengelolaan keuangan daerah yang ekonomis, efisien, dan efektif. Penerapan ASB dimaksudkan untuk meningkatkan efisiensi, efektivitas dan ekonomi RKA-APBD. Penyusunan ASB ini bertujuan untuk membentuk model yang digunakan untuk menilai kewajaran beban kerja dan biaya dalam melaksanakan kegiatan penyediaan bahan bacaan di Kabupaten Lumajang. Penelitian ini merupakan penelitian deskriptif dan dalam analisis data menggunakan metode Ordinary Least Square (OLS). Memodelkan ASB dengan analisis regresi dapat menghasilkan model yang wajar, apabila kegiatan-kegiatan yang anggaran belanjanya tidak wajar tidak diikutsertakan (adanya outlier), sehingga model regresi memiliki ketepatan tinggi dalam memprediksi total belanja setiap kegiatan.
\end{abstract}

Keywords : ASB, RKA-APBD, Ordinary Least Square (OLS), model regresi.

\section{Pendahuluan}

Penyusunan anggaran merupakan bagian dari fungsi manajemen yaitu perencanaan. Penyusunan anggaran yang kurang tepat dapat mengakibatkan terjadinya kekurangan/deficit dan kelebihan/over anggaran, misalnya kekurangan anggaran menyebabkan kegiatan terhenti dan kelebihan anggaran menimbulkan pemborosan.

Analisis Standar Belanja (ASB) sebagai salah satu instrumen anggaran berbasis kinerja telah diamanatkan sejak tahun 2000 yang diatur dalam Peraturan Pemerintah (PP) No.105 Tahun 2000 tentang Pengelolaan dan Pertanggung-jawaban Keuangan Daerah. Pada PP tersebut istilah yang masih digunakan adalah Standar Analisis Belanja (SAB). Berdasarkan PP tersebut, Kementerian Dalam Negeri Republik Indonesia menerbitkan pedoman operasional berupa Kepmen-dagri No.29 Tahun 2002 tentang Pedoman, Pengurusan, Pertanggungjawaban dan Pengawasan Keuangan Daerah serta Tata Cara Penyusunan Anggaran Pendapatan dan Belanja Daerah. Pada tahun 2004, keluar UndangUndang No.32 Tahun 2004 tentang Pemerintahan Daerah yang merupakan pengganti Undang-Undang No.22 Tahun 1999, dalam UU tersebut dikenalkan istilah baru yaitu istilah Analisis Standar Belanja (ASB).

ASB mempunyai maksud dan makna yang sama dengan Standar Analisis Belanja (SAB) yaitu suatu instrumen untuk penilaian kewajaran atas beban kerja dan biaya yang digunakan untuk melaksanakan suatu kegiatan. Pada tahun 2007 terbitlah Pemendagri No.59 sebagai penyempurnaan atas Permendagri No.13 Tahun 2006 tentang Pedoman Pengeloalan Keuangan Daerah. Dalam regulasi tersebut, disebutkan bahwa ASB merupakan satu instrumen pokok dalam penganggaran berbasis kinerja.

Pada saat ini, tuntutan transparansi dan akuntabilitas atas pengelolaan keuangan daerah semakin meningkat, karenanya untuk memenuhi tuntutan tersebut dapat dilakukan dengan cara pengelolaan keuangan daerah secara ekonomis, efisien, dan efektif. Penerapan 
ASB dimaksudkan untuk meningkatkan efisiensi, efektivitas dan ekonomi pembelanjaan pemerintah daerah, yang merupakan salah satu permasalahan pengelolaan keuangan daerah saat ini. Selain itu, penyusunan ASB ini penting dilakukan mengingat selalu muncul fenomena adanya ketidakadilan dan ketidakwajaran anggaran belanja antar kegiatan sejenis antar program dan antar SKPD.

Beberapa permasalahan lain dalam APBD yang akan timbul apabila tidak ada ASB adalah penentuan anggaran secara incremental, penentuan anggaran dipengaruhi oleh "Nama"e kegiatan dan "Siapa" yang mengajukan anggaran. Dalam lampiran Peraturan Menteri Dalam Negeri No. 32 Tahun 2008 Tentang Pedoman Penyusunan Anggaran Pendapatan dan Belanja Daerah dinyatakan bahwa seluruh SKPD dan SKPKD harus menyerahkan beberapa dokumen sebagai lampiran. Dokumen yang dimaksud meliputi KUA, PPAS, Analisis Standar Belanja dan Standar Satuan Harga.

Penyediaan bahan bacaan merupakan kegiatan yang penting bagi beberapa SKPD di Kabupaten Lembata, misalnya Dinas Pendidikan, Badan, Dinas, Kantor-kantor dan sebagainya. Namun, kegiatan ini seringkali tidak dilakukan dengan maksimal sehingga manfaat dari kegiatan tersebut tidak dapat dirasakan oleh pihak yang menerima. Penyusunan anggaran yang kurang tepat mengakibatkan terjadinya kekurangan dan kelebihan anggaran, sehingga menyebabkan kegiatan terhenti dan pemborosan. Oleh karena itu, guna mengurangi permasalahan tersebut diperlukan model ASB untuk menilai kewajaran beban kerja dan biaya sehingga tercapai penyusunan anggaran berbasis kinerja. Penyusunan ASB ini bertujuan untuk membentuk model yang digunakan untuk menilai kewajaran beban kerja dan biaya dalam melaksanakan kegiatan penyediaan bahan bacaan di Kabupaten Lumajang.

\section{Tinjauan Pustaka}

\subsection{Sistem Perencanaan dan Penganggaran}

Menurut Kumorotomo (2007), terdapat 2 (dua) hal penting dalam sistem manajemen keuangan yaitu sistem perencanaan dan sistem penganggaran. Sistem manajemen keuangan akan digunakan oleh pemerintah daerah dalam melakukan penganggaran. Pada dasarnya penganggaran yang dilakukan oleh pemerintah daerah merupakan lanjutan dari anggaran yang berasal dari pemerintah pusat yaitu dari rencana pembangunan jangka panjang pemerintah pusat (RPJPPP). Dalam implementasinya ada penyesuaian terutama berkaitan dengan penetapan beban kerja dan biaya dalam anggaran karena setiap daerah memiliki standar yang berbeda, hal ini bergantung pada kondisi ekonomi, sosial dan budaya suatu daerah. Gambaran dari uraian di atas akan terlihat dalam Gambar 2.1 


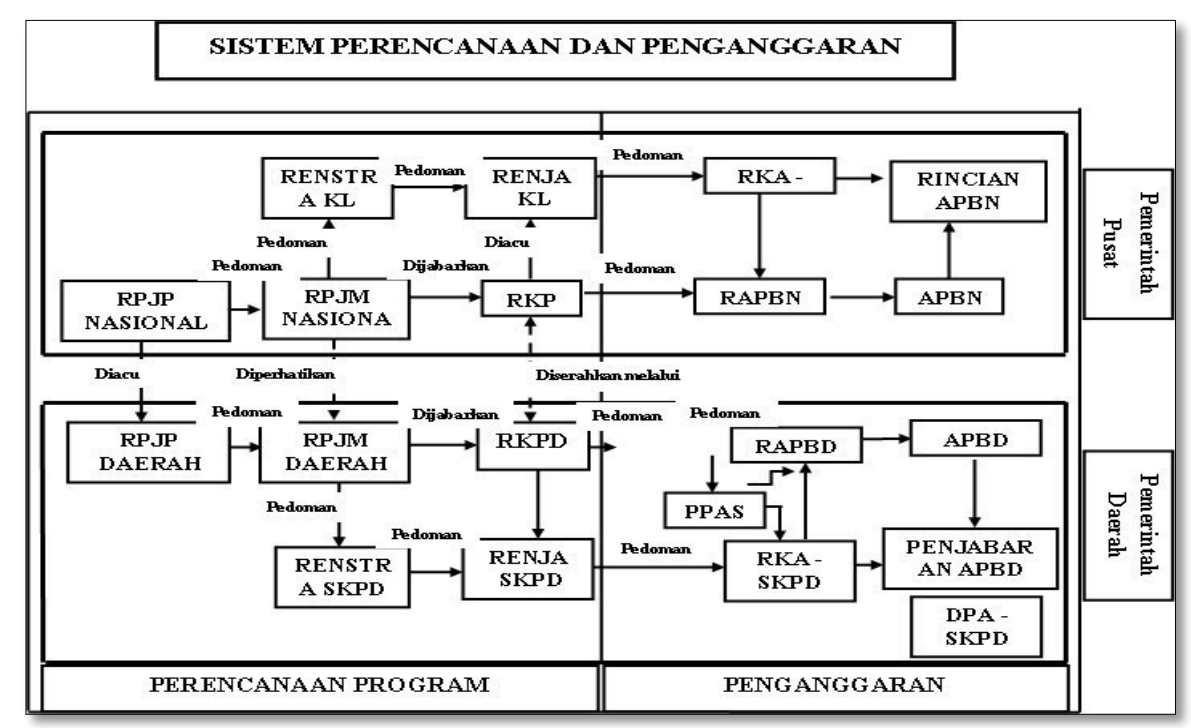

Gambar 2.1 Sistem Perencanaan dan Penganggaran

Sistem perencanaan dimaksudkan untuk mendukung sistem penganggaran. Dalam sistem ini rencana pembangunan di bagi dalam 3 rencana yaitu rancana pembangunan jangka pendek (1 tahun), rencana pembangunan jangka menengah (5 tahun) dan rencana pembangunan panjang (20 tahun).

Dalam sistem penganggaran, semua kegiatan berawal dari rencana pembangunan jangka menengah yang diakomodir dalam rencana kerja pembangunan daerah (RKPD). Dalam RKPD akan dijabarkan proritas pembangunan dan plafon dari anggaran dari masingmasing kegiatan/program pembangunan. Kemudian Prioritas kegiatan dijabarkan lebih rinci dalam rencana kerja anggaran (RKA) yang menjadi input dalam menyusun RAPBD. RKA didokumentasikan dalam rencana kerja anggaran satuan kerja perangkat daerah (RKA SKPD). Selanjutnya dari RAPBD dikemas lagi dalam ABPD dan dijabarkan dalam kegiatan dan program pembangunan yang telah disusun dalam RKPD.

\subsection{Anggaran Berbasis Kinerja}

Menurut Widjaja (2003), sebagai suatu sistem, perencanaan anggaran negara telah mengalami banyak perkembangan dan perubahan sesuai dengan dinamika manajemen sektor publik dan tuntutan yang muncul di masyarakat, sehingga saat ini berkembang sistem anggaran berbasis kinerja. Kinerja adalah gambaran pencapaian pelaksanaan suatu kegiatan/ program/ kebijaksanaan dalam mewujudkan sasaran, tujuan, misi dan visi organisasi. Dalam konteks daerah, konsep kinerja harus dianggap sebagai instrumen untuk mencapai tujuan dan bersifat relatif atau dapat diperbandingkan baik terhadap waktu maupun terhadap daerah atau SKPD lain.

Anggaran dapat diinterpretasikan sebagai paket pernyataan perkiraan penerimaan dan pengeluaran yang diharapkan akan terjadi dalam satu atau beberapa periode mendatang. Anggaran sektor publik adalah rencana kegiatan dan keuangan periodik (biasanya dalam periode tahunan) yang berisi program dan kegiatan dan jumlah dana yang diperoleh (penerimaan/pendapatan) dan dibutuhkan (pengeluaran/belanja) dalam rangka mencapai tujuan organisasi publik. Pedoman Penerapan Penganggaran Berbasis Kinerja, memiliki beberapa prinsip yang harus diikuti, prinsip tersebut meliputi: 1) Alokasi anggaran harus berorientasi pada kinerja (output and outcome oriented); 2) Fleksibilitas pengelolaan anggaran untuk mencapai hasil dengan tetap menjaga prinsip akuntabilitas (let the manager 
manages); 3) Money Follow Function, Function Followed by Structure.

Penyusunan anggaran berdasarkan kinerja pada dasarnya sudah dilakukan sejak Pemerintah Daerah mengajukan Kebijakan Umum APBD (KUA) dan Prioritas dan Plafon Anggaran Sementara (PPAS) harus ditentukan secara tegas berdasarkan hasil dan output-nya. Namun, penyusunan anggaran berdasarkan kinerja akan terlihat secara operasional pada setiap SKPD yang mengajukan RKA-SKPD (Rencana Kerja dan Anggaran Satuan Kerja Perangkat Daerah).

\subsection{Anggaran Pendapatan dan Belanja Daerah (APBD)}

Menurut Yani (2009), APBD merupakan rencana keuangan tahunan pemerintah daerah yang dibahas dan disetujui bersama oleh pemerintah daerah dan DPRD dan ditetapkan dengan peraturan daerah.

\subsubsection{Struktur APBD}

APBD merupakan satu kesatuan yang terdiri dari:

a. Pendapatan daerah,

b. Belanja daerah, dan

c. Pembiayaan daerah.

Pendapatan daerah meliputi semua penerimaan uang melalui rekening kas umum daerah, yang menambah ekuitas dana lancar, yang merupakan hak daerah dalam satu tahun anggaran yang tidak perlu dibayar kembali oleh daerah.

Pendapatan daerah sebagaimana dimaksud pada Pasal 20 ayat (1) huruf a terdiri atas:

a. Pendapatan Asli Daerah (PAD);

b. Dana perimbangan; dan

c. Lain-lain pendapatan daerah yang sah.

Pendapatan asli daerah terdiri atas:

a. Pajak daerah;

b. Retribusi daerah;

c. Hasil pengelolaan kekayaan daerah yang dipisahkan; dan

d. Lain-lain PAD yang sah.

Lain-lain PAD yang sah mencakup:

a. Hasil penjualan kekayaan daerah yang tidak dipisahkan;

b. Hasil pemanfaatan atau pendayagunaan kekayaan daerah yang tidak dipisahkan;

c. Jasa giro;

d. Pendapatan bunga;

e. Tuntutan ganti rugi;

f. Keuntungan selisih nilai tukar Rupiah terhadap mata uang asing; dan

g. Komisi, potongan ataupun bentuk lain sebagai akibat dari penjualan dan/atau pengadaan barang dan/atau jasa oleh daerah. 
Pendapatan dana perimbangan meliputi:
a. Dana Bagi Hasil;
b. Dana Alokasi Umum; dan
c. Dana Alokasi Khusus.

Lain-lain pendapatan daerah yang sah merupakan seluruh pendapatan daerah selain PAD dan dana perimbangan, yang meliputi hibah, dana darurat, dan lain-lain pendapatan yang ditetapkan pemerintah. Lain-lain pendapatan yang dimaksud di situ adalah pendapatan yang ditetapkan pemerintah seperti dana bagi hasil pajak dari propinsi ke kabupaten/kota dan dana ekonomi khusus.

Belanja daerah meliputi semua pengeluaran dari rekening kas umum daerah yang mengurangi ekuitas dana lancar, yang merupakan kewajiban daerah dalam satu tahun anggaran yang tidak akan diperoleh pembayarannya kembali oleh daerah. Belanja daerah dipergunakan dalam rangka pelaksanaan urusan pemerintahan yang menjadi kewenangan propinsi atau kabupaten/kota yang terdiri dari urusan wajib dan urusan pilihan yang ditetapkan dengan ketentuan perundang-undangan. Belanja daerah diklasifikasikan menurut organisasi, fungsi, program dan kegiatan, serta jenis belanja. Klasifikasi belanja menurut organisasi disesuaikan dengan susunan organisasi pemerintahan daerah. Organisasi pemerintahan daerah yang dimaksud seperti DPRD, kepala daerah dan wakil kepala daerah, sekretariat daerah, sekretariat DPRD, dinas, kecamatan, lembaga teknis daerah dan kelurahan.

\subsection{Analisis Standar Belanja (ASB)}

Menurut Mulyadi (2007), Analisis Standar Belanja (ASB) adalah standar yang digunakan untuk menganalisis kewajaran beban kerja atau biaya setiap program atau kegiatan yang akan dilaksanakan oleh suatu satuan kerja dalam satu tahun anggaran.

Penerapan ASB pada dasarnya akan memberikan manfaat antara lain :

1. Menentukan kewajaran belanja untuk melaksanakan suatu kegiatan sesuai dengan tupoksinya.

2. Meminimalisir terjadinya pengeluaran yang kurang jelas sehingga meng-akibatkan inefisiensi anggaran.

3. Meningkatkan efisiensi dan efektivitas dalam pengelolaan keuangan daerah.

4. Penentuan anggaran berdasarkan pada tolok ukur kinerja yang jelas.

\subsection{Posisi ASB Dalam Pengelolaan Keuangan Daerah}

Menururt Bastian (2006), ASB memiliki peran yang penting dalam berbagai tahap pengelolaan keuangan daerah, yaitu tahap perencanaan, penganggaran dan tahap pengawasan/pemeriksaan.

a. Tahap Perencanaan Keuangan Daerah

ASB dapat digunakan pada saat perencanaan keuangan daerah. ASB dapat digunakan pada saat Musrenbang, penyusunan rencana kerja SKPD (Renja SKPD), dan penyusunan Rencana Kerja Pemerintah Daerah (RKPD). Pada tahap tersebut ASB digunakan oleh para perencana untuk mengarahkan para pengusul kegiatan, baik masyarakat ataupun aparatur Pemda untuk fokus pada kinerja. 
b. Tahap Penganggaran Keuangan Daerah

ASB digunakan pada saat proses penganggaran Keuangan Daerah, yaitu pada saat penentuan plafon anggaran sementara dan penyusunan rencana kerja anggaran. ASB digunakan oleh Tim Anggaran Pemerintah Daerah (TAPD) untuk mengevaluasi usulan program, kegiatan, dan anggaran setiap satuan kerja dengan cara menganalisis antara kewajaran beban kerja dan biaya usulan program atau kegiatan bersangkutan.

c. Tahap Pengawasan/Pemeriksaan

Pada tahap pengawasan/pemeriksaan, para pengawas/pemeriksa dapat menggunakan ASB untuk menentukan batasan mengenai pemborosan dari suatu kegiatan.

\subsection{Pendekatan Perilaku Biaya}

Menurut Mulyadi (2007), biaya (cost) yang digunakan dalam menghasilkan suatu barang dan jasa baik di sektor swasta maupun publik dapat dikategorikan dalam 3 (tiga) jenis biaya, yaitu biaya tetap (fixed cost), biaya variabel (variable cost) dan biaya gabungan (mixed cost). Pemahaman akan jenis biaya ini akan sangat membantu dalam menentukan pembiayaan, pengawasan dan pembuatan keputusan, sehingga diperlukan pemahaman tentang perilaku biaya (cost behavior).

Biaya tetap (Fixed Cost) adalah biaya yang tidak mengalami perubahan (tidak naik dan tidak turun) pada skala tertentu, sekalipun output yang dihasilkan mengalami perubahan (naik/turun). Sebuah biaya disebut sebagai biaya variable (Variable Cost) jika dalam total terjadi perubahan jumlah output yang dihasilkan, maka jumlah biaya yang dialokasikan untuk menghasilkan barang/jasa tersebut juga berubah.

Pada dasarnya tidak mudah untuk mengelompokkan biaya tetap dan biaya variabel dalam kegiatan yang dilaksanakan di lingkungan pemerintah daerah. Biaya tersebut cenderung bersifat campuran, sehingga seringkali biaya yang diketahui hanya biaya total dan output yang dihasilkan dari suatu kegaitan. Dengan demikian, perlu dipisahkan biaya tersebut dalam biaya tetap dan variabel. Dalam memisahkan biaya total menjadi biaya tetap dan variabel, dapat digunakan metode regresi.

\subsection{Metode Estimasi Model Regresi}

Salah satu metode estimasi yang digunakan untuk menentukan perilaku cost adalah regresi. Metode ini menganggap bahwa hubungan antara cost dan volume of activity berbentuk garis lurus/linier $(\mathrm{Y}=\mathrm{a}+\mathrm{bX})$, dimana $\mathrm{Y}$ merupakan variabel tak bebas (dependent) dan $\mathrm{X}$ merupakan variabel bebas (independent).

Analisis regresi adalah analisis tentang studi ketergantungan satu variabel, variabel tak bebas, pada satu atau lebih variabel lain, variabel yang menjelaskan (explanatory varaiables), dengan maksud menaksir dan atau meramalkan nilai rata-rata hitung (mean) atau rata-rata (populasi) variabel tak bebas, dipandang dari segi nilai yang diketahui atau tetap (dalam pengambilan sampel berulang) variabel yang menjelaskan. Dalam proses pendugaan parameter regresi yaitu intercept (fixed cost) dan slope (average varbiable cost) dapat menggunakan metode kuadrat terkecil MKT (ordinary least squares OLS). Menurut Draper dan Smith (1992), bilamana analisis regresi hanya melibatkan satu variabel tak bebas dan beberapa (lebih dari satu) variabel bebas dan bentuk hubungannya linier, maka disebut regresi linier berganda.

Model untuk regresi linier berganda diberikan sebagai berikut:

$$
Y_{i}=\beta_{0}+\beta_{1} X_{1 i}+\beta_{2} X_{2 i}+\ldots . .+\beta_{k} X_{k i}+\varepsilon_{i}
$$


Dimana $\mathrm{Y}$ adalah variabel tak bebas (dependent), $\mathrm{X}$ adalah variabel bebas (independent), dan $\varepsilon$ adalah residual. Indeks $i$ menunjukkan observasi ke $i$, sedangkan indeks $k$ pada variabel bebas adalah untuk mengidentifikasi variabel yang bersangkutan. Jumlah dari variabel penjelas adalah $k$.

Penduga dari intersept dan slope dari model tersebut, biasanya dilambangkan dengan $b_{i}$ dapat diperoleh dengan OLS. Dalam proses pendugaan parameter model regresi berganda dapat menggunakan metode kuadrat terkecil (ordinary least square OLS). Metode OLS dalah metode yang meminimumkan jumlah kuadrat residual. Dimana residual merupakan selisih antara nilai peubah respon amatan dengan nilai peubah respon hasil prediksi model regresi yang diperoleh. Teori ekonomi pada umumnya menyatakan bahwa perubahan dari satu variabel bisa dijelaskan oleh perubahan beberapa (lebih dari satu) variabel lainnya.

Prinsip dasar dari metode kuadrat terkecil biasa adalah meminimumkan jumlah kuadrat residual, yaitu meminimumkan $\left(\varepsilon^{\prime} \varepsilon\right)$.

$$
\begin{gathered}
\sum_{\mathrm{t}=1}^{\mathrm{T}} \hat{\underline{\varepsilon}}_{\mathrm{t}}^{2}=\underline{\hat{\boldsymbol{\varepsilon}}^{\prime}} \underline{\hat{\boldsymbol{\varepsilon}}}=(\underline{\mathbf{Y}}-\mathbf{X} \hat{\boldsymbol{\beta}})^{\prime}(\underline{\mathbf{Y}}-\mathbf{X} \underline{\hat{\boldsymbol{\beta}}})=\underline{\mathbf{Y}^{\prime}} \underline{\mathbf{Y}}-2 \hat{\boldsymbol{\beta}}^{\prime} \mathbf{X}^{\prime} \underline{\mathbf{Y}}+\underline{\hat{\boldsymbol{\beta}}}^{\prime} \mathbf{X}^{\prime} \mathbf{X} \hat{\boldsymbol{\beta}} \\
\frac{\partial}{\partial \underline{\boldsymbol{\beta}}}\left(\underline{\hat{\boldsymbol{\varepsilon}}^{\prime}} \underline{\hat{\boldsymbol{\varepsilon}}}\right)=-2 \mathbf{X}^{\prime} \underline{\mathbf{Y}}+2 \mathbf{X}^{\prime} \mathbf{X} \underline{\hat{\boldsymbol{\beta}}}=0
\end{gathered}
$$

Sehingga didapatkan rumus:

$$
\left(\mathbf{X}^{\prime} \mathbf{X}\right) \stackrel{\hat{\beta}}{=}=\mathbf{X}^{\prime} \underline{\mathbf{Y}} \text { dan } \underline{\hat{\beta}}=\left(\mathbf{X}^{\prime} \mathbf{X}\right)^{-1} \mathbf{X}^{\prime} \underline{\mathbf{Y}}
$$

Penerapan metode kuadrat terkecil biasa merupakan cara pertama yang paling mungkin untuk dilakukan. Jika asumsi-asumsi dari regresi linier klasik terpenuhi, maka penduga metode kuadrat terkecil biasa akan mempunyai sifat BLUE (Best Linear Unbiased Estimator), yaitu tak bias dan mempunyai varian minimum dibandingkan dengan penduga tak bias lainnya.

\section{Metode Penelitian}

\subsection{Jenis dan Sumber Data}

Penyusunan ASB ini menggunakan data sekunder berupa data Rencana Kerja Anggaran (RKA) Pemerintah Kabupaten Lumajang Tahun 2015 yang diperoleh dari Dinas Pengelola Keuangan dan Aset Daerah (DPKAD).

\subsection{Metode Analisis Data}

Sebelum pembentukan model ASB terlebih dahulu dibentuk Cluster untuk setiap kegiatan yang telah dipilih menjadi kegiatan yang dibuatkan model ASB. Pembentukan Cluster dimaksudkan agar anggaran yang direncanakan disesuaikan dengan tingkatan SKPD. Secara umum terdapat enam Cluster, yaitu:

- Cluster 1 terdiri dari Badan, Dinas, Inspektorat, Sekret DPRD, Bidang pada Dinas Pendidikan

- Cluster 2 terdiri dari Kantor-Kantor dan Satpol PP

- Cluster 3 terdiri dari Bagian-bagian pada Sekretariat Daerah

- Cluster 4 terdiri dari Kecamatan 
- Cluster 5 terdiri dari Kelurahan

- Cluster 6 terdiri dari Unit Kerja Bidang Kesehatan

Tidak semua Cluster dapat dibuatkan model ASB karena terdapat Cluster tertentu yang memang tidak melaksanakan kegiatan tersebut dan/atau Cluster tersebut tidak menjabarkan cost driver secara rinci.

Dalam tahap pembentukan model ASB digunakan analisis regresi dengan metode pendekatan Ordinary Least Square (OLS) sebagai metode pendugaan parameter belanja tetap (fixed cost) dan belanja variabel (variable cost). Dalam penyusunan ASB ini, variabel tidak bebas yang digunakan adalah total biaya/pagu anggaran dari suatu kegiatan, sedangkan variabel bebas yang digunakan adalah cost driver dari kegiatan tersebut. Alokasi belanja setiap Cluster pada kegiatan yang dimodelkan ASB berbeda-beda berdasarkan kebutuhan inti yang diperlukan kegiatan tersebut. Perhitungan presentase rata-rata, batas bawah dan batas atas dari alokasi belanja menggunakan rumus sebagai berikut:

$$
\begin{aligned}
& \text { Rata }-\operatorname{rata}(\%)=\frac{\text { Rata }- \text { rata alokasi dana }}{\text { Total rata }- \text { rata alokasi dana }} \times 100 \% \\
& \text { B. } \operatorname{bawah}(\%)=\frac{\text { Rata }- \text { rata alokasi dana }-\frac{\text { standar deviasi }}{\sqrt{\text { banyaknya kegiatan }}}}{\text { Total rata }- \text { rata alokasi dana }} \times 100 \% \\
& \text { B. } \operatorname{atas}(\%)=\frac{\text { Rata }- \text { rata alokasi dana }+\frac{\text { standar deviasi }}{\sqrt{\text { banyaknya kegiatan }}}}{\text { Total rata }- \text { rata alokasi dana }} \times 100 \%
\end{aligned}
$$

\subsection{Tahapan Analisis Standar Belanja}

Terdapat 3 (tiga) tahap dalam penyusunan ASB, meliputi:

1. Tahap I, merupakan proses pengumpulan data RKA dari seluruh SKPD menjadi suatu database kegiatan.

2. Tahap II, merupakan proses pengelompokan database kegiatan menjadi beberapa kegiatan yang memiliki kemiripan pola kegiatan dan bobot kerja yang setara.

3. Tahap III, merupakan proses pembentukan model ASB dari Cluster yang ada pada kegiatan yang disetarakan.

\section{Hasil dan Pembahasan}

\subsection{Deskripsi Hasil Analisis}

Berdasarkan hasil rekapitulasi data Rencana Kerja Anggaran (RKA) dari 105 SKPD (organisasi) di Pemerintah Kabupaten Lumajang Tahun 2015 terdapat 2.930 kegiatan yang direncanakan. Dari 2.930 kegiatan tersebut, diperoleh 85 kelompok kegiatan yang memiliki kemiripan pola kegiatan dan bobot kerja yang sepadan. Berdasarkan 85 kelompok kegiatan tersebut, ditetapkan 14 kelompok kegiatan yang dapat dibuatkan model Analisis Standar Belanja (ASB). Secara umum jumlah maksimum cluster yang dapat terbentuk adalah 6 cluster dan minimal hanya terdapat 1 cluster untuk satu kegiatan yang di-ASB-kan. 


\subsection{Analisis Tahap I : Penyusunan Database}

Dalam penyusunan ASB tahap I diperoleh 2.930 rencana kegiatan yang berasal dari 105 SKPD (organisasi) Pemerintah Kabupaten Lumajang Tahun 2015. Dari database tersebut, di setiap SKPD (organisasi) terdapat informasi mengenai nama kegiatan yang diusulkan, keluaran kegiatan berupa tolok ukur kinerja, dan total pagu anggaran kegiatan. Berdasarkan database rencana kegiatan pada penyusunan ASB Tahap I, dilakukan analisis deskripsi terhadap variabel total pagu anggaran rencana kegiatan yang terdiri dari rata-rata nilai pagu anggaran, nilai minimum dan nilai maksimum rata-rata pagu anggaran.

\subsection{Analisis Tahap II : Penyetaraan Kegiatan ASB}

Penyusunan ASB tahap II dilakukan dengan mengelompokkan 2.930 rencana kegiatan yang berasal dari 105 SKPD (Organisasi) Pemerintah Kabupaten Lumajang Tahun 2015 menjadi 85 kelompok kegiatan yang tipikal. Tipikal di sini bermakna memiliki kemiripan pola dan bobot kerja yang sepadan antara satu kegiatan dengan kegiatan yang lain. Informasi mengenai nama SKPD (organisasi) yang mengusulkan, keluaran kegiatan berupa tolok ukur kinerja, dan total pagu anggaran dari 85 kelompok kegiatan. Berdasarkan 85 kelompok kegiatan yang dihasilkan dari penyusunan ASB Tahap II, dilakukan analisis deskriptif variabel total pagu anggaran rencana kegiatan yang terdiri dari rata-rata nilai pagu anggaran dari 85 kelompok kegiatan, nilai minimum dan nilai maksimum rata-rata pagu anggaran.

\subsection{Analisis Tahap III}

\subsubsection{Pembentukan Model ASB}

Pada tahap III dilakukan pembentukan model ASB dengan menggunakan analisis regresi dengan pendekatan metode kuadrat terkecil (MKT) dalam proses pendugaan parameter belanja tetap (fixed cost) dan belanja variabel (variable cost). Variabel bebas yang digunakan untuk pemodelan ASB adalah cost driver sedangkan variabel tak bebasnya adalah pagu anggaran kegiatan.

Dalam penyusunan ASB kegiatan Pemerintah Kabupaten Lumajang dari 85 kelompok kegiatan yang memilki kemiripan pola kegiatan dan bobot kerja yang sepadan, dipilih 14 kelompok kegiatan yang di-ASB-kan. Dasar pertimbangannya adalah karena 14 kelompok kegiatan tersebut dianggap tipikal ada di setiap SKPD. Dalam setiap kegiatan dibentuk cluster berdasarkan kesetaraan tingkatan SKPD, agar model ASB yang didapat setara. Maksimal terdapat 6 cluster dan minimal terdapat 1 cluster pada setiap kegiatan. Hal ini dikarenakan tidak semua cluster melakukan kegiatan tersebut.

Selanjutnya dilakukan pendokumentasian/ perumusan ASB dari tahap-tahap sebelumnya. Berikut adalah hasil dalam pembentukan model ASB-01 untuk jenis kegiatan Penyediaan Bahan Bacaan dapat dilihat pada tabel berikut : 
Tabel 4.1. Model ASB-01 Penyediaan Bahan Bacaan

\begin{tabular}{|c|l|c|c|c|}
\hline Cluster & $\begin{array}{l}\text { Pengendali } \\
\text { Belanja } \\
\text { (Cost driver) }\end{array}$ & $\begin{array}{c}\text { Pengendali } \\
\text { Belanja } \\
\text { Tetap } \text { (Fixed } \\
\text { Cost) }\end{array}$ & $\begin{array}{c}\text { Pengendali } \\
\text { Belanja } \\
\text { Variabel } \\
\text { (Variable Cost) }\end{array}$ & Formula ASB \\
\hline \multirow{2}{*}{1} & \begin{tabular}{l} 
Jumlah \\
Bahan \\
Bacaan \\
(Eksemplar) \\
dalam Durasi \\
\cline { 3 - 5 } 3
\end{tabular} & $\operatorname{Rp} 759.000$ & $\operatorname{Rp} 73.208$ & $\begin{array}{c}\text { Rp 759.000+ (Rp 73.208 x } \\
\text { Jumlah Bacaan) }\end{array}$ \\
\cline { 3 - 5 } & Satu Tahun & Rp 5.679.057 & Rp 67.210 & $\begin{array}{c}\text { Rp 5.679.057 + (Rp 67.210 } \\
\text { x Jumlah Bacaan) }\end{array}$ \\
\hline
\end{tabular}

\section{Deskripsi:}

Kegiatan pengadaan bahan bacaan merupakan kegiatan yang bertujuan untuk memenuhi kebutuhan bahan bacaan di lingkungan Badan, Dinas, Inspektorat, Sekretariat DPRD dan Bidang pada Dinas Pendidikan (Cluster 1). Cost driver merupakan banyaknya bahan bacaan yang disediakan selama satu tahun. Satuan yang digunakan adalah eksemplar. Eksemplar untuk bahan bacaan koran/majalah adalah jumlah jenis koran/majalah yang terbit tiap bulan dalam satu tahun (jumlah jenis x bulan). Eksemplar untuk bahan bacaan lainnya adalah jumlah jenis bacaan tiap volume yang terbit dalam satu tahun (jumlah jenis bahan bacaan $\mathrm{x}$ volume).

Pengendali Belanja (cost driver):

Jumlah Bahan Bacaan (Eksemplar) dalam Durasi Satu Tahun

Satuan Pengendali Belanja Tetap (fixed cost):

$=\operatorname{Rp} 759.000,00$ per kegiatan

Satuan Pengendali Belanja Variabel (variable cost):

$=\operatorname{Rp} 73.208,00$ per jumlah bacaan

\section{Rumus Perhitungan Belanja Total:}

$=$ Belanja Tetap + Belanja Variabel

$=\operatorname{Rp} 759.000+(\operatorname{Rp} 73.208 \times$ Jumlah Bacaan $)$

Alokasi Objek Belanja Cluster 1:

\begin{tabular}{|l|c|c|c|c|}
\hline \multicolumn{1}{|c|}{ Objek Belanja } & $\mathbf{N}$ & $\begin{array}{c}\text { Rata-rata } \\
(\boldsymbol{\%})\end{array}$ & $\begin{array}{c}\text { Batas Bawah } \\
(\boldsymbol{\%})\end{array}$ & $\begin{array}{c}\text { Batas Atas } \\
(\boldsymbol{\%})\end{array}$ \\
\hline Belanja Jasa Kantor & 21 & 55,86 & 25,85 & 85,87 \\
\hline $\begin{array}{l}\text { Belanja Modal Aset Tetap dan } \\
\text { Lainnya }\end{array}$ & 2 & 44,14 & 5,52 & 82,76 \\
\hline \hline Jumlah Bacaan (eksemplar) & 61 & 36 & 85 \\
\hline Pagu Anggaran (Rp) & 5.189 .833 & 2.733 .607 & 7.646 .060 \\
\hline
\end{tabular}

Keterangan : Terdiri atas 21 kegiatan 


\subsubsection{Kelayakan Model ASB}

Pada proses pembentukan model ASB didapatkan informasi mengenai kelayakan model. Model layak ketika nilai variabel cost $\left(\mathrm{B}_{1}\right)$ signifikan $(p$-value $<\alpha=0,05)$ dan model tidak layak ketika nilai variabel cost $\left(\mathrm{B}_{1}\right)$ tidak signifikan ( $p$-value $\left.>\alpha=0,05\right)$. Berapa pun nilai $\mathrm{N}$ (jumlah data), jika sudah signifikan maka model dianggap layak digunakan. Hanya saja kebaikan model masih bergantung pula pada nilai $R$-square. Nilai $R$-square yang rendah menunjukkan bahwa model ASB kurang dapat menggambarkan keragaman data.

Tabel 4.2. Kelayakan Model ASB-01 Penyediaan Bahan Bacaan

\begin{tabular}{|c|c|c|c|c|l|}
\hline Cluster & N & R-square & Sig & $\begin{array}{c}\text { Layak/ } \\
\text { Tidak Layak }\end{array}$ & Keterangan \\
\hline 1 & 21 & 0.55 & 0.00 & Layak & \\
\hline 2 & 4 & 0.64 & 0.20 & Tidak Layak & - Nilai variable cost $\left(\beta_{1}\right)$ tidak signifikan \\
\hline 3 & 3 & 0.97 & 0.11 & Tidak Layak & - Nilai variable cost $\left(\beta_{1}\right)$ tidak signifikan \\
\hline
\end{tabular}

Dari tabel tersebut, dapat diketahui bahwa model ASB yang layak digunakan adalah model ASB Cluster 1.Model ASB yang telah dibuat dapat membantu dalam menentukan Total Belanja suatu rencana kegiatan. Penggunaan Model ASB dapat dilakukan dengan beberapa tahapan. Tahapan-tahapan dalam menggunakan model ASB adalah sebagai berikut:

1. Misalkan akan dilakukan kegiatan Penyediaan Bahan Bacaan yang dilakukan oleh Dinas Pendidikan. Dengan jumlah bacaan sebanyak 61 eksemplar dalam waktu satu tahun. Dalam hal ini 61 eksemplar dalam waktu 1 tahun merupakan cost driver yang digunakan.

2. Menentukan maksimum total belanja untuk kegiatan tersebut berdasarkan rumus yang ada. Dengan menggunakan model ASB di atas, maka total belanja akan dihitung sebagai berikut :

Total Belanja $=\operatorname{Rp} 759.000+(\operatorname{Rp} 73.208 \times$ Jumlah Bacaan $\times$ Jumlah Tahun $)$

Total Belanja $=\operatorname{Rp} 759.000+(\operatorname{Rp} 73.208 \times 61 \times 1)$

$=\operatorname{Rp} 759.000+\operatorname{Rp} 4.465 .688$

$=\mathrm{Rp} 5.224 .688$

Dari hasil tersebut, dapat diketahui bahwa maksimum total belanja untuk kegiatan tersebut sebesar Rp 5.224.688

3. Alokasikan Total Belanja tersebut ke komponen-komponen belanjanya sesuai dengan persentase yang telah ditentukan (misalnya menggunakan rata-rata), yaitu:

\begin{tabular}{|c|c|c|}
\hline Objek Belanja & Jumlah & Persentase $(\%)$ \\
\hline Belanja Jasa Kantor & Rp 2.918.511 ${ }^{1)}$ & 55,86 \\
\hline Belanja Modal Aset Tetap dan Lainnya & $\operatorname{Rp} 2.306 .177^{2)}$ & 44,14 \\
\hline Jumlah & Rp 5.224.688 & 100 \\
\hline
\end{tabular}

Perhitungan besarnya belanja untuk setiap objek belanja:
1) Belanja Jasa Kantor
$=55,86 \% \times \operatorname{Rp} 5.224 .688$
2) Belanja Cetak dan Penggandaan
$=\operatorname{Rp} 2.918 .511$
$=44,14 \% \times \operatorname{Rp} 5.224 .688$
$=\operatorname{Rp} 2.306 .177$ 


\section{Kesimpulan dan Saran}

Kesimpulan yang dapat diambil dari penelitian ini adalah Penyusunan ASB untuk setiap kegiatan sebenarnya dapat dilakukan dengan menghitung ulang beban kerja dan biaya setiap kegiatan berdasarkan keluarannya. Bila terdapat kegiatan yang memiliki keluaran dan cost driver yang sama maka dapat digolongkan ke dalam satu golongan kegiatan dengan jumlah anggaran yang relatif sama besar (adil).

Penggunaan analisis regresi untuk memodelkan anggaran belanja merupakan suatu pendekatan yang cukup praktis, efektif dan efisien. Tujuan menggunakan analisis regresi dalam penyusunan ASB adalah untuk menentukan kewajaran dari nilai belanja dibandingkan dengan beban kerja dari suatu kegiatan. Memodelkan ASB dengan analisis regresi dapat menghasilkan model yang wajar, apabila kegiatan-kegiatan yang anggaran belanjanya tidak wajar tidak diikutsertakan (adanya outlier), sehingga model regresi memiliki ketepatan tinggi dalam memprediksi total belanja setiap kegiatan.

Implementasi Analisis Standar Belanja (ASB) merupakan salah satu upaya meminimalkan permasalahan anggaran setiap kegiatan SKPD. Melalui ASB dapat ditentukan patokan standar, sehingga nilai anggaran atau total belanja kegiatan tidak berlebihan atau dapat diukur. Rekomendasi dari kajian ini antara lain:

1. Dalam pencapaian efisiensi anggaran berbasis kinerja, sebaiknya dilakukan penyeragaman indikator kinerja keluaran (output) suatu kegiatan SKPD, sehingga indikator tersebut dapat dijadikan cost driver untuk kegiatan yang setara

2. Perlu pembaruan (up date) ASB di setiap tahun dengan pertimbangan terjadi perubahan harga-harga umum sebagai akibat inflasi dan lain-lain.

\section{Daftar Pustaka}

Bastian, I. 2006. Akuntansi Sektor Publik.Erlangga.Yogyakarta.

Draper, N.R. and H. Smith. 1992. Applied Regression Analysis.Second Edition, John Wiley and Sons, Inc. New York.

Kumorotomo, W. 2007. Penganggaran dan Penilaian Kewajaran Standar Analisis Belanja (SAB).

Mulyadi, 2007. Activity Based Cost System: Sistem Informasi Biaya Untuk Pemberdayaan Karyawan, Pengurangan dan Penentuan Secara Akurat Kos Produk dan Jasa.Yogyakarta : BPFE Universitas Gadjah Mada.

Widjaja, A. 2003. Activity Based Budgeting. Bandung: Harvarindo.

Yani, A. 2009. Hubungan Keuangan antara Pemerintah Pusat dan Daerah di Indonesia. Jakarta : Rajawali Pers. 